\title{
Geomorphological and geochemical characterization of the 11 August 2008 mud volcano eruption at S. Barbara village (Sicily, Italy) and its possible relationship with seismic activity
}

\author{
P. Madonia ${ }^{1}$, F. Grassa ${ }^{1}$, M. Cangemi ${ }^{2}$, and C. Musumeci $^{3}$ \\ ${ }^{1}$ Istituto Nazionale di Geofisica e Vulcanologia, Sezione di Palermo, Via Ugo La Malfa 153, 90146 Palermo, Italia \\ ${ }^{2}$ Göttingen Zentrum Geowissenschaften, Abteilung Geobiologie, Universität Göttingen, Goldschmidtstrasse 3, \\ 37077 Göttingen, Germany \\ ${ }_{3}^{3}$ Istituto Nazionale di Geofisica e Vulcanologia, Sezione di Catania, Piazza Roma 2, 95123 Catania, Italia
}

Received: 18 November 2010 - Revised: 14 March 2011 - Accepted: 23 March 2011 - Published: 24 May 2011

\begin{abstract}
On 11 August 2008 a paroxysmal eruption occurred at Santa Barbara mud volcano (MV), located close to Caltanissetta, one of the most densely populated cities of Sicily (Italy). An associated minor event took place on August 2009. Both the events caused severe damage to civil infrastructures located within a range of about $2 \mathrm{~km}$ from the eruptive vent. Geomorphological, geochemical, and seismological investigations were carried out for framing the events in the appropriate geodynamic context. Geomorphological surveys recognized, in the immediate surrounding of the main emission point, two different families of processes and landforms: (i) ground deformations and (ii) changes in morphology and number of the fluid emitting vents. These processes were associated to a wider network of fractures, seemingly generated by the shock wave produced by the gas blast that occurred at the main paroxysm. Geochemical characterization allowed an estimation of the source of the fluids, or at least their last standing, at about $3 \mathrm{~km}$ depth. Finally, the close time relationships observed between anomalous increments of seismic activity and the two main paroxysmal events accounted for a possible common trigger for both the phenomena, even with different timing due to the very different initial conditions and characteristics of the two processes, i.e. seismogenesis and gas overloading.
\end{abstract}

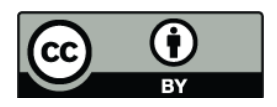

Correspondence to: P. Madonia (p.madonia@pa.ingv.it)

\section{Introduction}

Mud volcanoes, hereafter referred as MVs, are geological structures formed as a result of the emission of argillaceous material on the Earth's terrestrial or on the sea floor. Overpressured multiphase pore fluids, mainly water and methane, which are incorporated in this material, make it semi-liquid and force it up through fissures in the crust, producing an outflowing mass of mud on the surface. Usually, mud volcanism occurs along convergent plate margins where fluid-rich sediments (especially marine clay) are buried in deep-sea trenches at high rates, giving place to density inversion. This is mainly due to considerable amount of seawater trapped in the intergranular spaces (primary density inversion) or secondary buoyancy due to lateral influx of fluids, hydrocarbon formation, diagenetic and metamorphic processes or tectonic, that remove material or modify the overbunden stress field (Kopf, 2002). The extruded material forms characteristic isometric to elongated morphological structures varying both in shape (from isometric elevations of plano-conical shapes rising some hundred meters above the adjacent countryside to irregular shapes) and size (ranging from tens of square meters to very large structures up to $100 \mathrm{~km}^{2}$ ), composed by mud breccia sharply contrasting to the surrounding host sediments (Dimitrov, 2002). Currently $>1800$ mud volcanoes are known in many modern accretionary complex areas, with high sedimentation rates originating as a result of rapid overloading caused by structural or tectonic thickening (Dimitrov, 2002). Mud volcanoes are normally in a quiescent stage because of the short duration of eruptions often characterized by vigorous seepage of water, gas, and

Published by Copernicus Publications on behalf of the European Geosciences Union. 
petroleum. Being a preferential pathway for methane-rich rising fluids and mud, sedimentary volcanoes can be considered as a source of natural hazard, especially if located inside or very close to urbanized areas or areas frequented by ecotourism. In recent times, the most striking example is the Lusi mud volcano eruption in Indonesia (Java Island), started on 29 May 2006 (Mazzini et al., 2009), still ongoing after four years, spewing about 100000 tons a day of mud that has since caused the death of 14 people and the evacuation of more than 60000 .

If mud volcanoes are considered a potential source for natural hazards, two critical questions in forecasting possible paroxysmal events is: at which extent can mud volcano eruptions be related or immediately triggered by earthquakes? Or said another way, does mud volcano activity increase for a period of time after nearby earthquakes? Strain and stress perturbations from large earthquakes influence systems as groundwater aquifers, hydrocarbon or geothermal systems, and magmatic volcanoes at long distances (e.g. Beresnev and Johnson, 1994; Gomberg and Davis, 1996; Linde and Sacks, 1998; Gomberg et al., 2001; Roeloffs et al., 2003). As reported in literature, earthquakes can also trigger large methane mud volcano eruptions (Abikh, 1863; Aliyev, 2004). Examples of mud volcano activity associated with seismic activity have been documented in Pakistan (Delisle et al., 2002), Romania (Baciu and Etiope, 2005), Italy (Martinelli and Dadomo, 2005), Turkmenistan (Guliyev and Feizullayev, 1995), and Japan (Chigira and Tanaka, 1997). Another example of earthquake/mud volcano relationship is represented by a mud volcano on the island of Baratang in the Middle Andaman islands that erupted just several minutes after the 2004 great Sumatra-Andaman Islands $M=9$ earthquake (Mellors et al., 2007). Finally, the previously mentioned Lusi mud volcano eruption is the subject of a hot scientific controversy over its trigger mechanism, which some authors attribute to an earthquake (Mazzini et al., 2009; Sawolo et al., 2009), whereas other studies implicate the drilling activity of a nearby oil well (Davies et al., 2010).

The present work describes the mud volcano paroxysmal eruption that occurred on 11 August 2008 at the Santa Barbara Village, located in Caltanissetta, one of the most densely populated cities of Sicily (Italy).

The chronology of the events and their geomorphological and geochemical characterizations are described, with special attention paid to the possible relationship with the seismic activity of Central Sicily and its possible role as a triggering mechanism of the volcano-sedimentary paroxysms.

\section{Geological setting}

Sicily is located in the Central Mediterranean, along the main Eurasia-Nubia convergent plate boundary (Dewey et al., 1989; Serpelloni et al., 2007; Catalano et al., 2008), where three main elements mark both the collisional complex

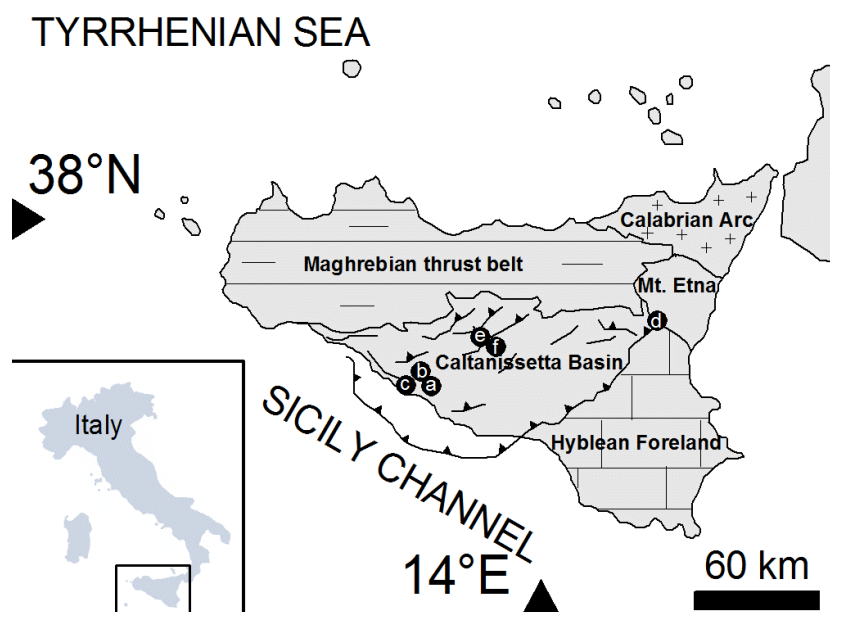

Fig. 1. Structural setting of Sicily with location of onshore mud volcanoes. (a) Maccalube at Aragona; (b) Fuoco di Censo at Bivona; (c) Bissana at Cattolica Eraclea; (d) Salinelle at Paternò; (e) Marianopoli; (f) Santa Barbara.

of Sicily and its offshore continuation (Fig. 1): (i) the Hyblean Foreland outcropping in southeastern Sicily; (ii) the Caltanissetta Basin, a dynamic foredeep basin from the Late Miocene to the Quaternary; and (iii) a complex chain, thrust towards the east and southeast, consisting of the Calabrian Arc and the Maghrebian thrust belt (Vallone et al., 2008 and references therein).

In this regional geodynamic setting, Sicily is characterized by earthquakes and mud volcano activities. In Sicily, mud volcanoes essentially occur over the accretionary wedge developed in front of the Sicilian-Maghrebian fold-and-trust belt and originate in the clastic sediments deposited in a system of amalgamated thrust-top basins (Caltanissetta Basin) that were progressively shortened and displaced during the late Miocene to Pleistocene (e.g. Monaco and Tortorici, 1996; Lickorish et al., 1999, and references therein). Sicilian mud volcanoes occur onshore (Etiope et al., 2002) and offshore (Holland et al., 2003; Savini et al., 2009; Cangemi et al., 2010), located in similar geologic settings, characterized by rapid sedimentation since the Late Cenozoic and affected by intense neotectonics. Onshore mud volcanoes have been widely described by Etiope et al. (2002) who recognized (see Fig. 1) the Maccalube at Aragona, the Fuoco di Censo at Bivona, the Bissana at Cattolica Eraclea, and two different sites, the Salinelle S. Biagio and the Salinelle Stadio, at Paternò. All of these mud volcanoes are typically smaller than those generally occurring in other hydrocarbon-prone areas, some of these characterized by water pools of several meters in diameter where gases gurgle vigorously (Etiope et al., 2002). Other onshore mud volcanoes are located close to the city of Caltanissetta: at Marianopoli (Graziano, 2009) and at Santa Barbara Village, the later being the object of this study. 
The first historical notices on sedimentary volcanism in Caltanissetta are reported by the abbot Ferrara (1822) and Li Volsi (1826), who documented paroxysmal eruptions in 1783, 1817, 1819, and 1823.

The local geological succession (ICS, 2004) spans from Late Miocene to Quaternary. Its bottom is represented by Tortonian (Middle-Upper Miocene) clays (Argille Brecciate II) (Ogniben, 1954). They are covered by the evaporites of the Gessoso-Solfifera Formation, deposited during the Messinian (Upper Miocene) salinity crisis in the Mediterranean Sea and consisting, from bottom to top, of bedded diatomites (Tripoli Formation), limestones (sometimes evaporitic), and gypsum deposits interbedded with clay levels. The Trubi Formation, stratigraphically continuous but geometrically discordant, covers the Gessoso-Solfifera Formation and consists of marls and marly limestones of Zanclean age (Low Pliocene). The Trubi Formation is interlayered and/or covered by the Argille Brecciate IV Formation (Early Pliocene) (Ogniben, 1954), consisting of clay deposits with olistostromic intercalations. These deposits widely outcrop in the studied area, with no soil coverage and enclose exotic elements from older formations.

\section{Materials and methods}

Positions of fluid emitting vents and fracture network were acquired by three differential GPS surveys, carried out on 13 August, 11 September 2008, and 26 April 2010, using a pair of Thales Magellan single frequency GPS units; position data were post-processed using the Thales Mobile Mapper software, with a final position error of $0.3 \mathrm{~m}$. All the data have been analyzed in a GIS environment (Quantum GIS, release 1.0.2) and overlaid on a georeferenced raster base map at the nominal scale of 1:10000.

The isopach map of the muddy material expelled during the paroxysmal events was generated with a kriging algorithm using Golden Software Surfer (release 8) from both direct measurements on the boundary of the deposit and altitude differences (maximum error $0.2 \mathrm{~m}$ ) measured along a transect by the use of a laser distantiometer MDL Laser Ace equipped with an electronic accelerometer for zenithal angles determination. The buried topography (altitude errors estimated in few tens of centimetres, thanks to the regular ground surface around vent locations and the presence of topographical ground control points) was subtracted from the measures prior to their elaboration.

Chemical-physical parameters ( $\mathrm{pH}, \mathrm{Eh}$, electric conductivity and water temperature) were measured directly in the field on 9 August 2010 by portable Orion devices. Water samples from the same vents were collected and stored for $24 \mathrm{~h}$ in 11 PET bottles for decanting most of the suspended clay material. Water was then twice filtered, using in sequence 1.2 and $0.45 \mu \mathrm{m}$ filters (Acrodisk), and stored in $50 \mathrm{cc}$ PET bottles, stabilizing the sample for cation anal- ysis with one drop of $0.1 \mathrm{~N}$ chloridric acid. Dissolved ions were analyzed using an ion chromatograph (Dionex DX120) equipped with columns for anions (AS14A) and cations (CS12A), with the exception of bicarbonates, determined by titration.

Water stable isotope ratios were determined on the filtered aliquot. The $\delta \mathrm{D}$ and $\delta^{18} \mathrm{O}$ compositions were determined using on-line pyrolysis system and $\mathrm{CO}_{2}$-water equilibration conventional technique respectively. Isotope ratios, reported in delta notation vs V-SMOW international standard, were measured with a CF-IRMS (Delta Plus, Thermo Bremen, Germany). Analytical precision for each measurement was better than $0.1 \%$ or for $\delta^{18} \mathrm{O}$ and $1 \%$ ofor $\delta \mathrm{D}$.

Earthquake locations in Central Sicily, located within an area defined by a rectangle with coordinates $37^{\circ} .14-37^{\circ} .74$ latitude (N) and $13^{\circ} .68-14^{\circ} .72$ longitude (E) and covering the period 2002-2009, have been investigated by considering National Seismic Network data (available through http:// bollettinosismico.rm.ingv.it/) integrated with those collected by the local Sicilian Seismic Network (Gruppo Analisi Dati Sismici, 2011). The seismic networks, managed by the Istituto Nazionale di Geofisica e Vulcanologia (INGV), consist of about 90 seismic stations distributed all over Sicily, but mainly operating in the eastern part. Epicentral distribution of the events were located using the computer program Hypoellipse (Lahr, 1999).

\section{The 11 August 2008 eruption}

\subsection{Description of the event and morphological evolution of the area}

The Santa Barbara Village (Fig. 2) is located in the southeasternmost part of the city of Caltanissetta; it was originally built up in the second half of the last century as a miner's housing project. The State Road no. 122 separates the Santa Barbara Village from Contrada Terrapelata ("Terrapelata" means "nude ground" in Italian, evidently referring to the total absence of soil coverage and vegetation typical of sedimentary volcanism); within Contrada Terrapelata, the fluid emitting vents are located in a place called "Vulcanello" (little volcano).

In the early morning of 11 August 2008, as reported by several witnesses, a telluric event occurred in Contrada Terrapelata, with an intensive breaking of the soil in fractures with horizontal and vertical displacements, causing diffuse disasters to the closest infrastructures: factories, retaining walls, electric and hydraulic facilities, private buildings, and in a school. At the same time, a separate network of fractures occurred at the southern suburb of Caltanissetta (Sant'Anna), $2 \mathrm{~km}$ away from Contrada Terrapelata. Some hours later in the afternoon of the same day, two or more jets of mud, gas, and water, accompanied by a very strong hiss audible 


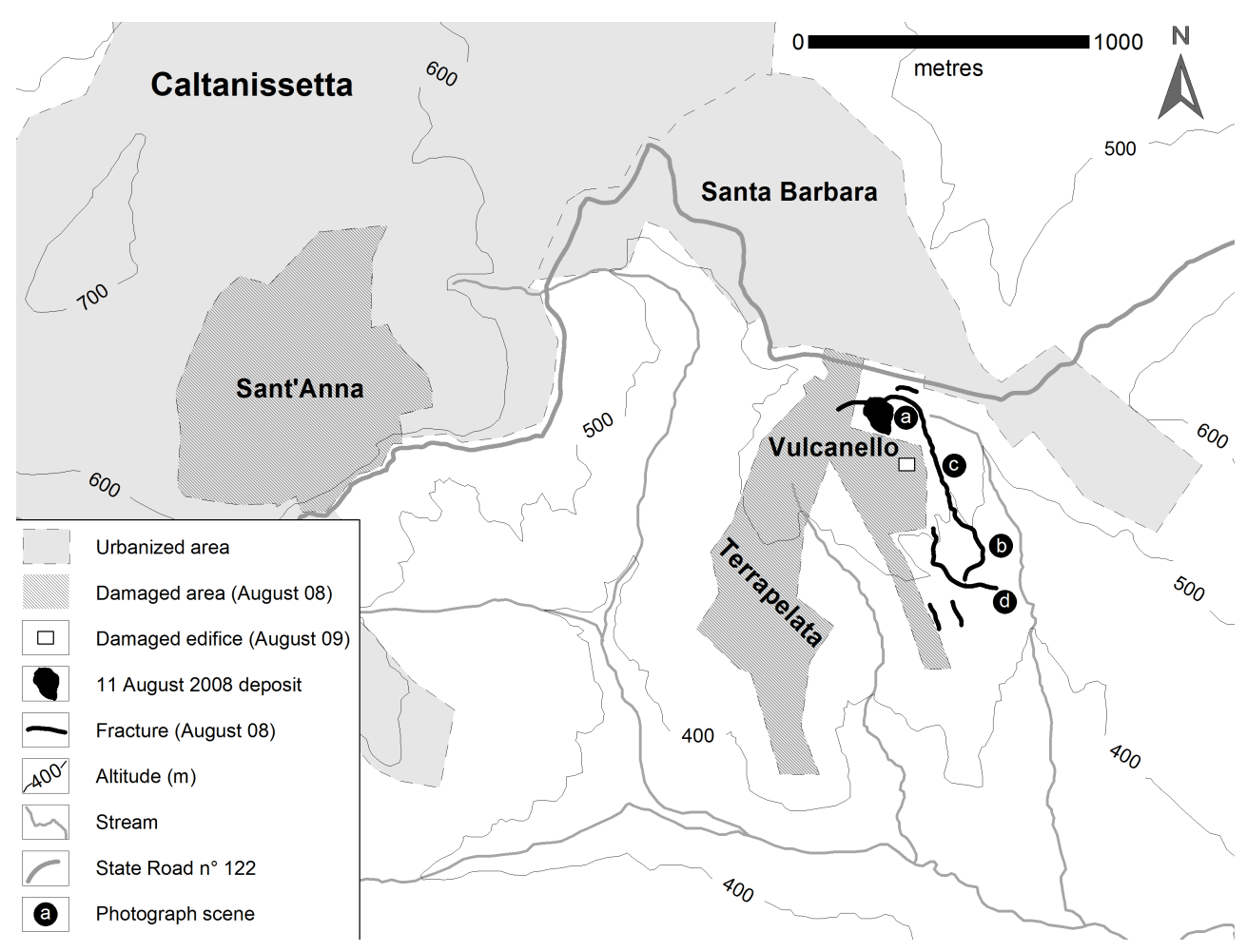

Fig. 2. Topographic map of Santa Barbara area, with localization of the main features and damaged areas related to mud volcanoes activity.

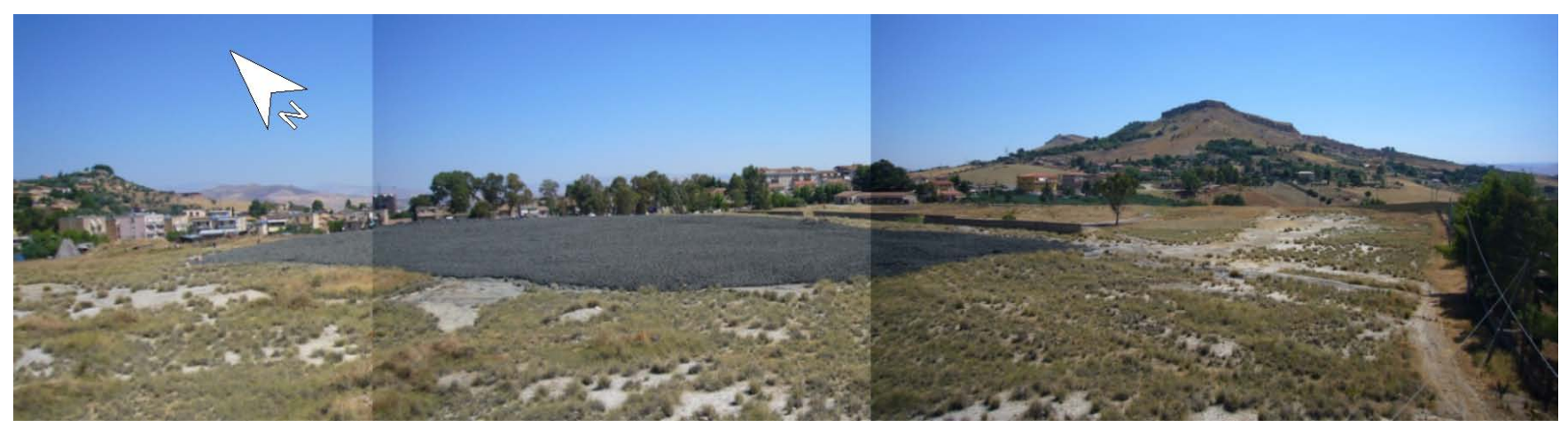

Fig. 3. View of Vulcanello area two days after the 11 August 2008 paroxysmal event. The grey clay deposit is the material erupted by the paroxysm.

at several hundreds of meters of distance, were ejected from the mud volcanoes up to $20-30 \mathrm{~m}$ above the ground.

The paroxysmal phenomenon lasted several minutes and covered the Vulcanello area (Fig. 3) with a muddy deposit that quickly assumed a leaf shape due to a slow southward movement along a very gentle hillslope.

As revealed by the GPS survey carried out two days later (13 August, Fig. 4a), the neo-formed mud deposit occupied an area of about $12000 \mathrm{~m}^{2}$, with the emitting vents located in its upper quarter. The deposit consisted of very wet clay with chaotic structure within which numerous lithic fragments, from a few decimetres to several centimetres in diameter, were found. As shown in the isopach map reported in Fig. 5, the deposit reached its maximum thickness of about $3.5 \mathrm{~m}$ around the vents, whereas at its boundary it was $0.3 \mathrm{~m}$ thick without any differences between the up- and down-slope portions. Based on the isopach map, the total volume of the emitted material was estimated about $9500 \mathrm{~m}^{3}$.

A total of 21 vents were individuated, all located around the maximum thickness area supposed to be the main emission point of the paroxysmal eruption; 13 of these vents were emitting a very fluid mud through small (tens of centimetres) pools with bubbling gas, whereas the other 8 were emitting only gas and were disposed in a half-circle close to the 

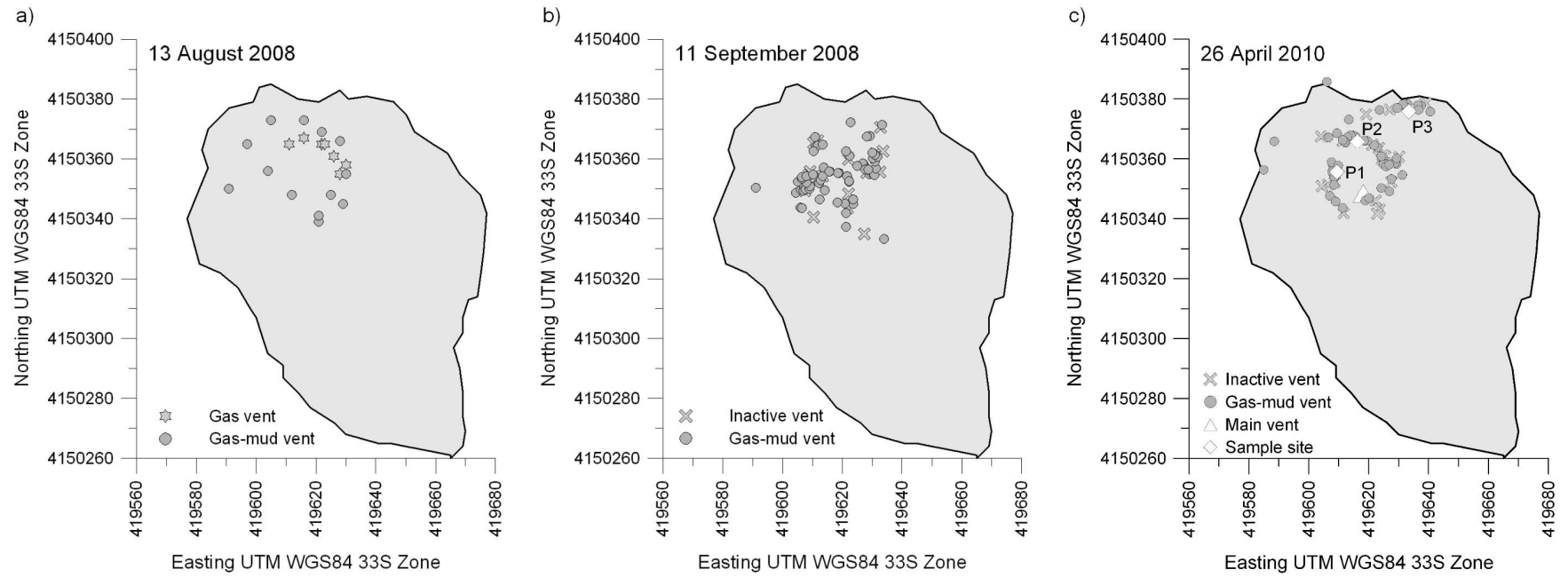

Fig. 4. Perimeter of mud volcano deposit (grey area) of the 11 August 2008 eruption with location of the emitting vents in three different periods: (a) 13 August 2008 (b) 11 September 2008; (c) 26 April 2010.

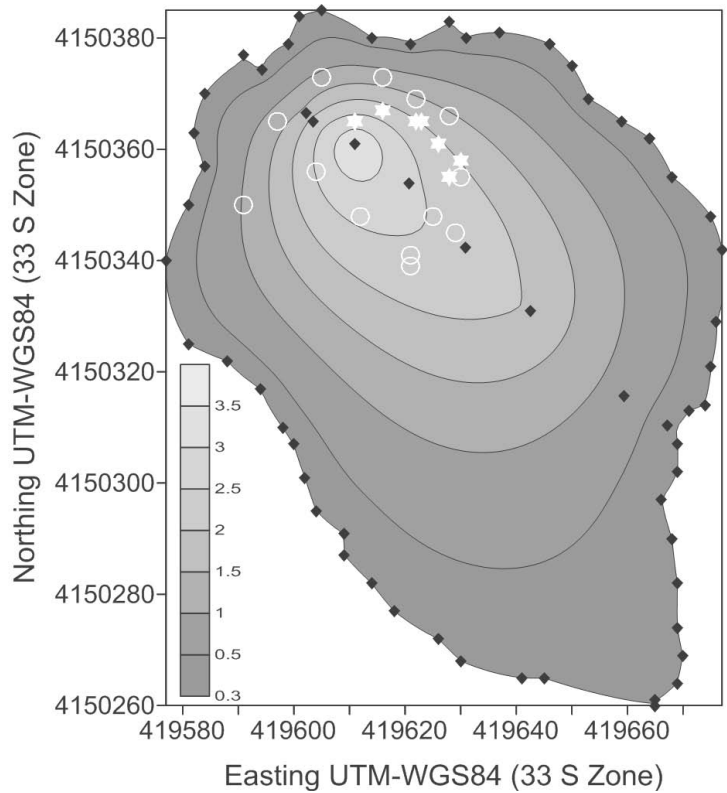

Fig. 5. Isopach map of the 11 August 2008 mud volcano deposit; black diamonds are the thickness measuring points, white void circles the mud emitting vents, white stars the gas emitting vents.

maximum thickness point. In addition to the concentrated emissions, the entire vent area was characterized by diffuse degassing from the cracks.

A second survey carried out one month after the eruption (11 September 2008, Fig. 4b) evidenced significant qualiquantitative variations in fluid emissions, which have continued since the paroxysm. A total of 81 vents were recognized in the field, 63 of which emitting fluid mud with bubbling gas and 18 inactive (small pools of stagnant fluid mud); the vents were randomly distributed, with the exception of an ESE-NNW alignment of few points at the southern border of the vent area.

After the 11 August 2008 paroxysm, only one minor anomalous emission has occurred in the Vulcanello area: a network of fractures that, in the first half of August 2009 , opened across an edifice (immediately cleared after the event) located about $250 \mathrm{~m} \mathrm{SSE}$ of Vulcanello (see Fig. 2 for its location). During an inspection carried out on 12 August 2009 , the sound of bubbling and methane concentrations up to $10 \%$ vol was recorded into that fractures, evidencing the presence of a secondary, peripheral vent field under the building.

A control survey was exploited on 26 April 2010, whose results are summarized in Fig. 4c. The total number of vents was nearly the same as the 11 September 2008 survey: 74 instead of 81,54 of which were emitting mud and gas and 20 were inactive. Two very evident structures were marked by vent positions: (i) a sub-circular ring around a main vent and (ii) a SSW-ENE alignment immediately northward from the previous feature.

Changes in number and locations of the emitting vents have been accompanied by a parallel morphological evolution of the conic-shaped neo-forms growing around each point of mud-dominated upwelling fluids. As shown in Fig. 6a, 2 days after the paroxysm (13 August 2008), the vents opened at the same level as the new topographical surface, with the rising mud uniformly flowing around them. Six days after (Fig. 6b, 17 August 2008) the vents started to show ancestral pseudo-volcanic forms (few centimetres high), with an emitting vent of sub-circular shape located at their tops. After a month (Fig. 6c, 17 September 2008), the study area newly resembling a typical mud-volcano landscape, with well defined pseudo-volcanic features several 

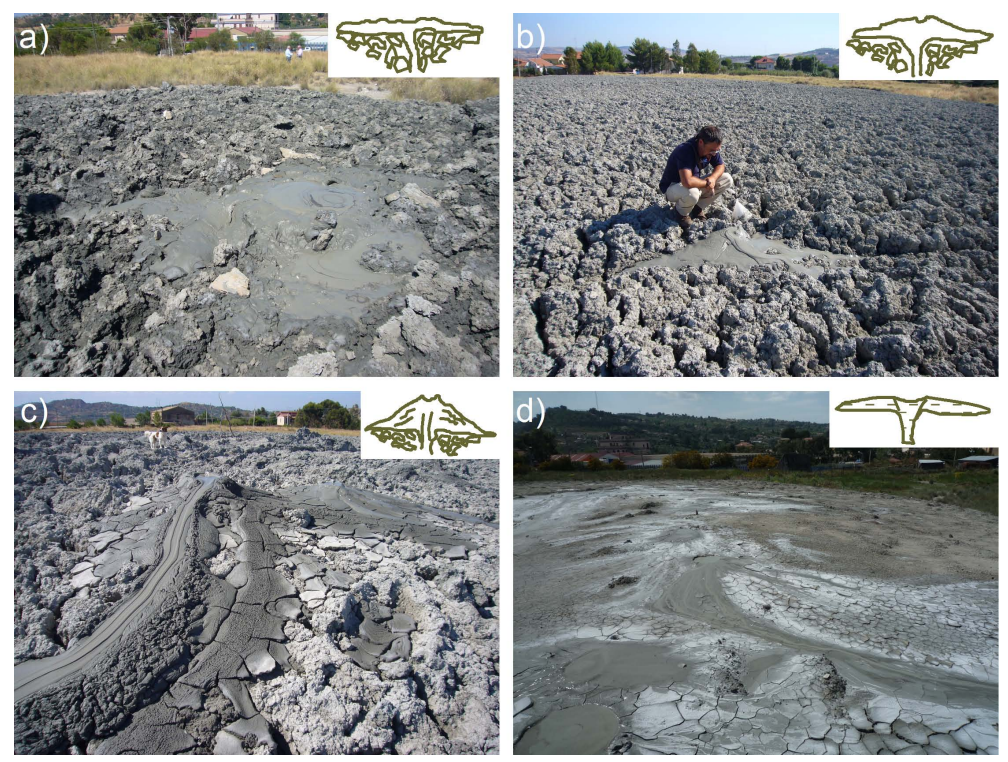

Fig. 6. Field photographs taken at different times illustrating the morphological features of the emitting vents (simplified cross-sections in graphical insets): (a) 13 August 2008; (b) 17 August 2008; (c) 17 September 2008; (d) 26 April 2010.
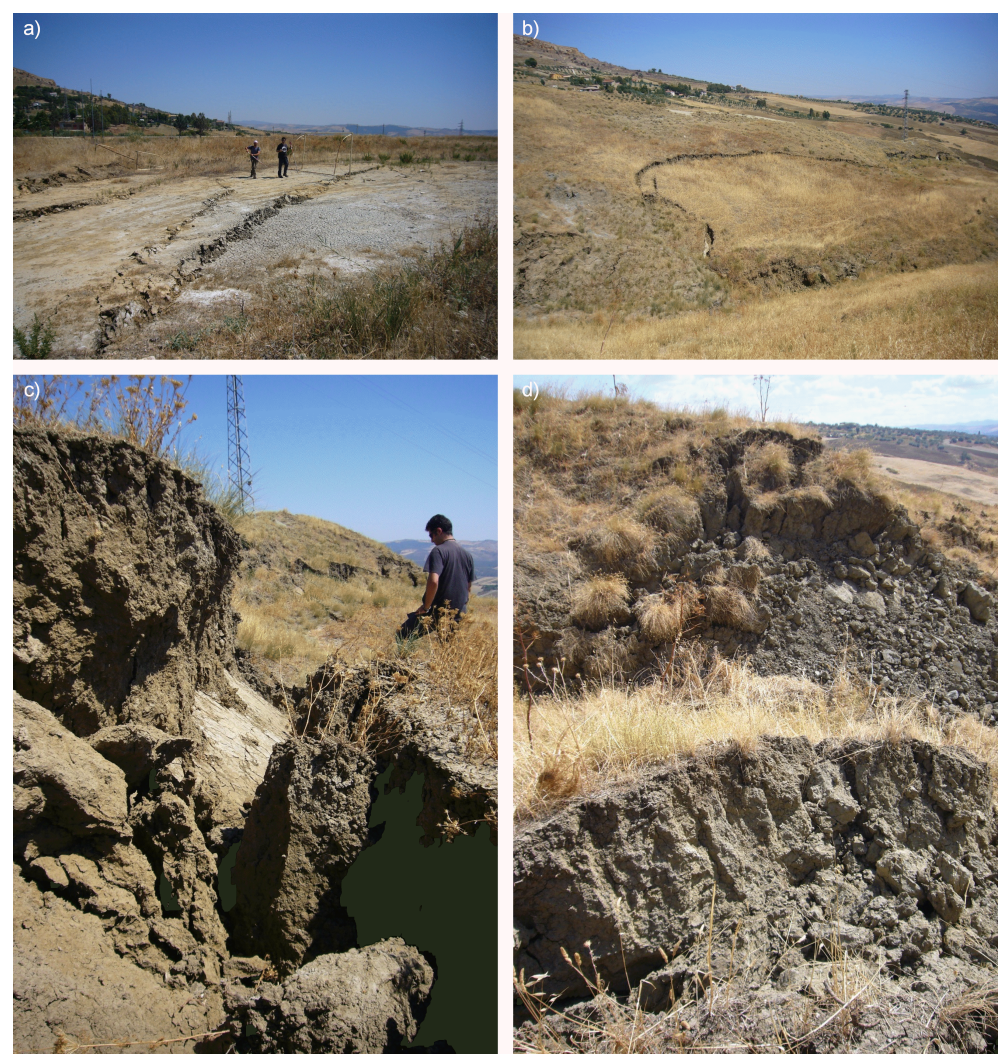

Fig. 7. Details of the fracture network originated from the 11 August 2008 event: (a) simple cracks with centimetric displacements associated to features of higher dimensions in the immediate surroundings of the vents; (b) portions of slopes cut by discontinuities with both horizontal and vertical movements; (c) particular of the previous rupture line; (d) brecciation of the clay deposits at the foot of the steepest slopes in the southern boundary of the studied area. 

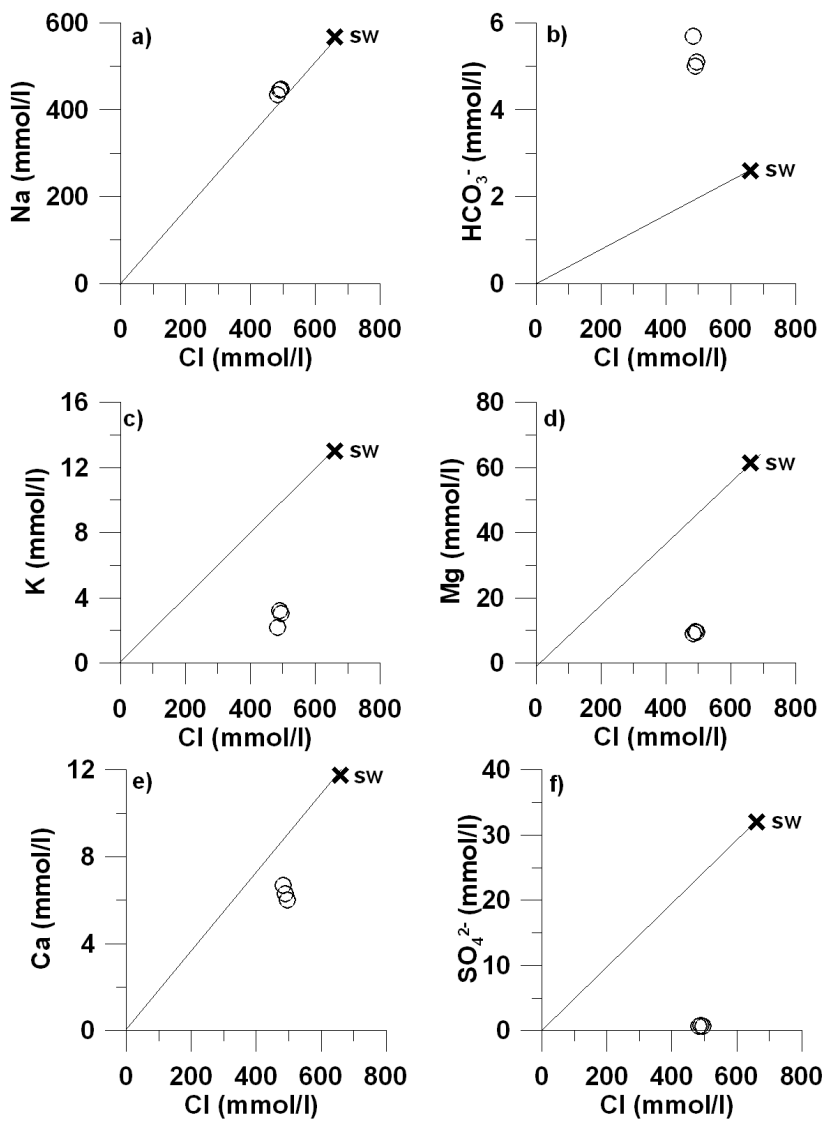

Fig. 8. Plots of major and minor constituent vs. Cl. Na (a), alkalinity (b), $\mathrm{K}(\mathbf{c}), \mathrm{Mg}$ (d), $\mathrm{Ca}(\mathbf{e})$ and $\mathrm{SO}_{4}$ (f). Mixing line between freshwater and Mediterranean seawater is also reported.

tens of centimetres high, emitting mud flowing apart in well separated arms. A little less than two years after the paroxysm (Fig. 6d, 26 April 2010) all the features appeared very enlarged but smoothed in elevation, due to the interactions between the constructive action of the continuously upwelling mud and the rainfall-driven erosion.

The morphological features due to the 11 August 2008 eruption were not limited to the area strictly surrounding the main emission point, but extended far away as an articulated network of fractures. As reported in Fig. 2, these fractures were not limited to the immediate surroundings of the eruptive vents, and developed for more than $1 \mathrm{~km}$ along the fluvial valleys running toward south from Vulcanello. The horizontal and vertical displacements across the fractures were not related to their distance from the mud volcanoes. As shown in Fig. 7, simple cracks with centimetric displacements (Fig. 7a) were observed together with features of higher dimensions in the immediate surroundings of the vents. At hundreds of meters of distance, entire portions of slopes (Fig. 7b) were cut by discontinuities, with both horizontal and vertical movements two orders of magnitude higher (Fig. 7c). Another phenomenon related to the eruption
Table 1. Physico-chemical parameters and concentrations of major elements in the collected waters. Water temperature is expressed in ${ }^{\circ} \mathrm{C}, \mathrm{EC}$ ( = electrical conductivity) in $\mathrm{mS} \mathrm{cm}^{-1}, \mathrm{pH}$ in $\mathrm{pH}$ units, Eh in $\mathrm{mV}$. Concentrations are expressed in $\mathrm{mgl}^{-1}$ and TDS in $\mathrm{g}^{-1}$. Alk $=$ total alkalinity reported as $\mathrm{HCO}_{3}$. Isotopic composition is reported in delta per mil vs. V-SMOW. SI = saturation index: $\mathrm{a}=$ aragonite; $\mathrm{c}=$ calcite; $\mathrm{d}=$ dolomite; $\mathrm{anh}=$ anhydrite; $\mathrm{g}=$ gypsum..

\begin{tabular}{lrrrr}
\hline & $\mathrm{P} 1$ & $\mathrm{P} 2$ & $\mathrm{P} 3$ & $\mathrm{MSW}$ \\
\hline$T^{\circ} \mathrm{C}$ & 26.8 & 26.1 & 29.9 & \\
$\mathrm{pH}$ & 7.47 & 7.58 & 7.52 & 8.20 \\
$\mathrm{EC}$ & 30.2 & 37.3 & 39.4 & 54.4 \\
$\mathrm{Eh}$ & -42 & 25 & 60 & \\
$\mathrm{Na}$ & 10261 & 10196 & 9924 & 13007 \\
$\mathrm{~K}$ & 120 & 125 & 87 & 508 \\
$\mathrm{Mg}$ & 227 & 236 & 220 & 1494 \\
$\mathrm{Ca}$ & 241 & 252 & 268 & 471 \\
$\mathrm{Cl}$ & 17541 & 17354 & 17124 & 23397 \\
$\mathrm{Br}$ & 41 & 25 & 44 & 78 \\
$\mathrm{SO} 4$ & 61 & 71 & 68 & 3072 \\
$\mathrm{Alk}$ & 311 & 305 & 348 & 159 \\
$\delta \mathrm{D}$ & -7.0 & -6.0 & -11.0 & 11.0 \\
$\delta^{18} \mathrm{O}$ & 10.1 & 10.6 & 10.1 & 1.6 \\
$\mathrm{TDS}$ & 28.8 & 28.6 & 28.5 & 42.2 \\
$\mathrm{Na} / \mathrm{Cl}$ & 0.91 & 0.91 & 0.90 & 0.86 \\
$\mathrm{SIa}$ & 0.13 & 0.24 & 0.49 & \\
$\mathrm{SIc}$ & 0.28 & 0.39 & 0.64 & \\
$\mathrm{SId}$ & 0.47 & 0.67 & 1.13 & \\
$\mathrm{SIanh}$ & -2.59 & -2.52 & -2.32 & \\
SIg & -2.44 & -2.36 & -2.20 & \\
\hline
\end{tabular}

was the brecciation of the clay deposits (Fig. 7d) ubiquitously outcropping in the southern sector of the study area, which occurred especially at the foot of the steepest slopes.

\subsection{Water and stable isotopes geochemistry of the emitted fluids: a hypothesis on their origin}

Major and minor dissolved constituents and isotopic compositions are reported in Table 1. The collected waters have a salinity around $28 \mathrm{gl}^{-1}$ and near-neutrality $\mathrm{pH}$ values. $\delta \mathrm{D}$ and $\delta^{18} \mathrm{O}$ values are around $-8 \%$ and $+10 \%$ respectively.

Waters emitted from S. Barbara MVs have a chemical composition resembling that of seawater, with $\mathrm{Na}$ and $\mathrm{Cl}$ as the most abundant dissolved elements. Freshening with a low- $\mathrm{Cl}$ component $(\mathrm{Cl}$ is about $25 \%$ lower than seawater) and some relevant modifications, both in chemical (enrichment in $\mathrm{Na}$ and alkalinity and a depletion in $\mathrm{K}, \mathrm{Mg}$, $\mathrm{Ca}$ and $\mathrm{SO}_{4}$ ) and isotopic composition (enrichment in ${ }^{18} \mathrm{O}$ and depletion in ${ }^{2} \mathrm{H}$ ), with respect to the original seawater composition were also observed (Fig. 8a-f, and Fig. 9). 


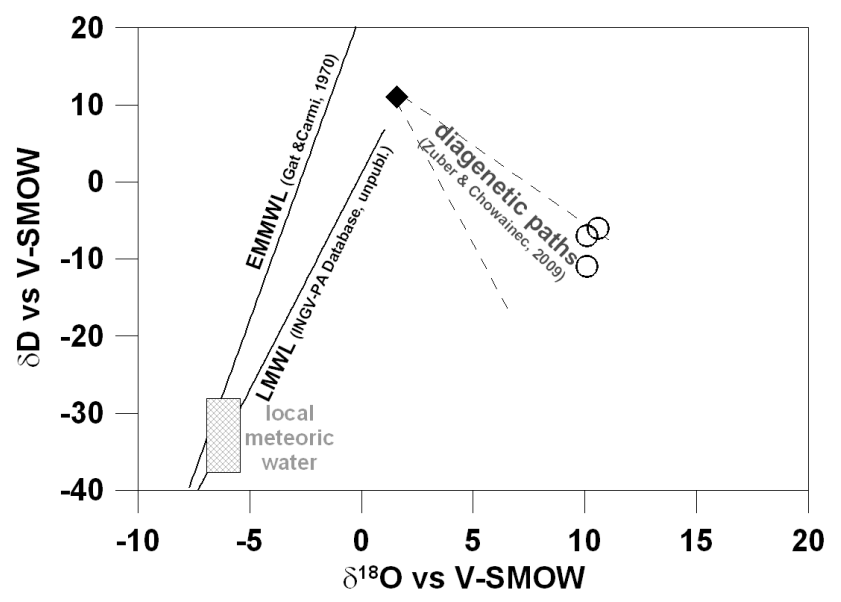

Fig. 9. Oxygen-18 vs. Deuterium plot showing Eastern Mediterranean Meteoric Water Line (EMMWL) of Gat and Carmi (1970), Local Meteoric Water Line and the field of local meteoric water (INGV Database, unpublished data). Water stable isotopes suggest waters are modified by diagenetic processes.

Many of these features, which are common to both fluids emitted from some onshore MVs areas (Dia et al., 1999; You et al., 2004) and pore waters associated with several submarine mud volcanoes (Martin et al., 1996; Fitts and Brown, 1999; Brown et al., 2001; Dählmann and De Lange, 2003), are most likely the result of diagenetic processes.

The marked depletion in sulphate ions is a possible evidence of bacterial sulphate reduction, associated with degradation of organic matter and/or anaerobic oxidation of methane (Murray et al., 1978), that takes place in these waters as follows:

$$
\begin{aligned}
& 2 \mathrm{CH}_{2} \mathrm{O}+\mathrm{SO}_{4}^{2-} \Leftrightarrow \mathrm{H}_{2} \mathrm{~S}+2 \mathrm{HCO}_{3}^{-}+\mathrm{H}_{2} \mathrm{O} \\
& \mathrm{CH}_{4}+\mathrm{SO}_{4}^{2-} \Leftrightarrow \mathrm{HS}^{-}+\mathrm{HCO}_{3}^{-}+\mathrm{H}_{2} \mathrm{O}
\end{aligned}
$$

Increasing of dissolved inorganic carbon content also result from these reactions.

The collected waters also show an enrichment in $\mathrm{Na}$ concurrent to depletion in $\mathrm{K}$. This is likely due to the illitization of smectites (Hower et al., 1976) and/or ion-exchange reactions between waters and clay minerals (Martin et al., 1996).

The contents of calcium and magnesium, lower than seawater $\left(<6 \mathrm{mMl}^{-1}\right.$ and $<10 \mathrm{mMl}^{-1}$ respectively), suggest that these two elements are involved in intense watersediment exchanges at high temperature, as already observed in waters emitted from Taiwanese mud volcanoes (You et al., 2004) and/or in the precipitation of secondary Ca- and Mgbearing carbonates, mostly enhanced by increased dissolved inorganic carbon contents.

Mineral saturation indices (SI), calculated by the PHREEQC computer program (Parkhurst and Appelo, 1999), indicate that the waters are saturated or slightly oversaturated with respect to dolomite (SId $0.47 \div 1.13$ ), calcite

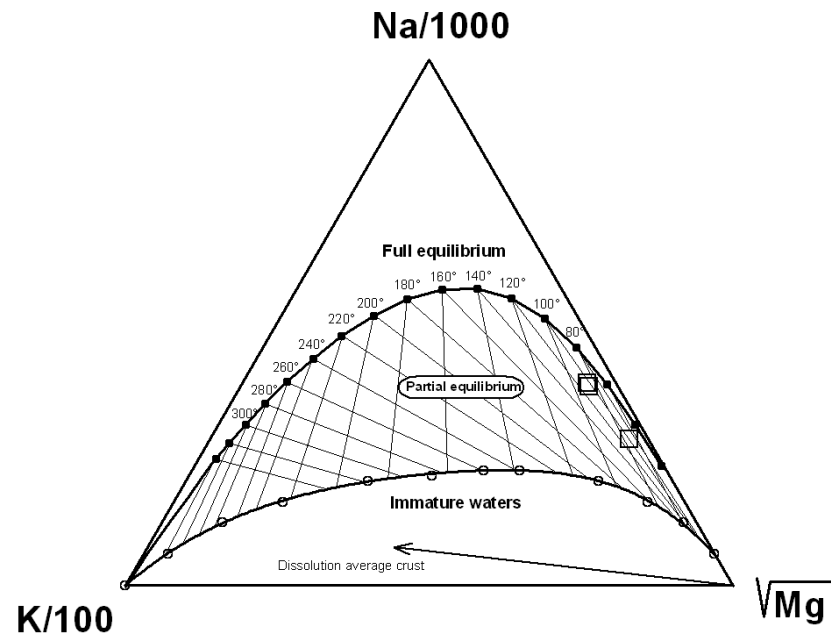

Fig. 10. Ternary Na-K-Mg diagram (after Giggenbach, 1988). Collected waters fall with the "partial equilibrium" field at temperatures between 80 and $130^{\circ} \mathrm{C}$ (concentrations in $\mathrm{mgl}^{\circ}$ ).

(SIc $0.28 \div 0.92$ ), aragonite (SIa $0.13 \div 0.78$ ) and magnesite (SIm $0.10 \div 0.6$ ), while these are strongly undersaturated with respect to gypsum $(\mathrm{SIg}-2.4 \div-2.2)$ and anhydrite (SIanh $-2.6 \div-2.3$ ).

From an isotopic point of view, all the collected waters show unusual positive $\delta^{18} \mathrm{O}$ values. In the $\delta \mathrm{D} / \delta^{18} \mathrm{O}$ diagram (Fig. 9), they fall on the right of both the reference line for Mediterranean rainwater (EMMWL) (Gat and Carmi, 1970) and the local meteoric waters (INGV-Palermo internal database, unpublished data), roughly following the so-called "diagenetic paths" (Zuber and Chowaniec, 2009).

As already suggested for the MVs associated with other modern accretionary prisms (Brown et al., 2001; Dählmann and De Lange, 2003), pore water freshening and positive oxygen-18 values could be related to low-grade mineral transformations (smectite dewatering, smectite/illite, opal dehydration) and/or to gas hydrates destabilization. The latter process can be ruled out, since water released during gas hydrate formation is expected to be enriched in heavy isotopes with respect to the pristine isotopic composition of water from which gas hydrate were originated.

On the contrary, dewatering of carbonate-free oceanic clay sediments should produce water depleted in $\delta \mathrm{D}$ and enriched in $\delta^{18} \mathrm{O}$ values (Magaritz and Gat, 1981).

Therefore, assuming that waters emitted from the S. Barbara MVs result from a binary mixing between seawater and interlayer water released from dewatering of smectite (diagenetic waters), by using a simple mass balance equation a value of about $-90 \%$ o for $\delta \mathrm{D}$ and $+35 \%$ ofor $\delta^{18} \mathrm{O}$ may be inferred for diagenetic water. These values fit well the isotope signature of both diagenetic water inferred from porewater extracted from MVs sediments on the Moroccan Margin (Mazurenko et al., 2003) and those assessed for the Eastern 
$-38^{\circ} \mathrm{N}$
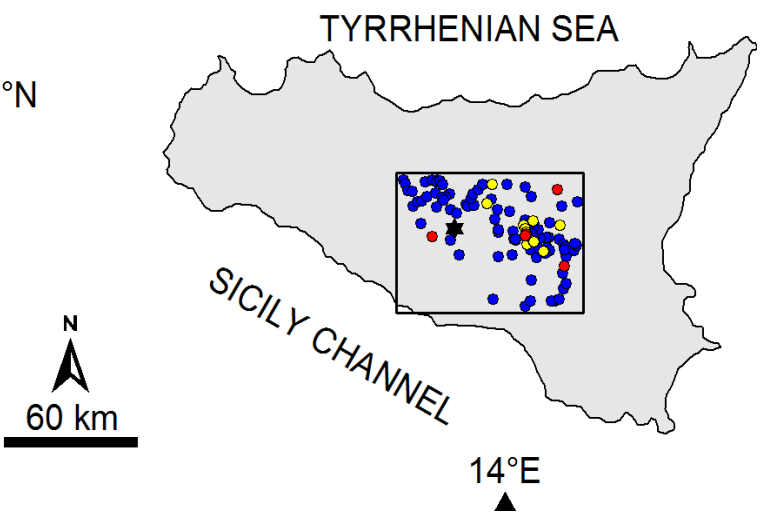

Fig. 11. Epicentral location of all the seismic events recorded in Central Sicily during the 2002-2009 period. Red circles are the August 2008 events, yellow circles are the August 2009 events, and blue circles all the others. The black star is the Santa Barbara area.

Mediterranean submarine MVs, assuming that water is released from smectite/illite transformation at temperatures of $150^{\circ} \mathrm{C}$ (Dählmann and De Lange, 2003).

As previously argued, the chemical and isotope composition of the waters associated with S. Barbara MVs suggest that freshening of initial seawater is probably due to interlayer water released from clay minerals lattice during diagenesis.

These diagenetic reactions, including mineralogical transformations, geochemical and biochemical processes, occur between water and sediments at different steps: early stages of compaction, burial processes, tectonic deformation, or during the upwelling of deeper fluids flowing through the overlying sedimentary sequence.

In order to constrain the depth of the source of S. Barbara MVs waters, some theoretical ionic solutes geothermometers, based on temperature-dependent mineral exchange reactions, have been applied.

The triangular Na-K-Mg plot (Fig. 10), which combines both the $\mathrm{Na} / \mathrm{K}$ and the $\mathrm{K} / \mathrm{Mg}$ geothermometers in a unique diagram (Giggenbach, 1988), highlights that these waters have partially reached their thermodynamic equilibrium with minerals, pointing to an equilibrium temperature around $110^{\circ} \mathrm{C}$ (range $88-128^{\circ} \mathrm{C}$ ).

Such an estimation fits very well with the temperature range $\left(60-80^{\circ} \mathrm{C}\right)$ during which the smectite starts its transformation into illite, thus leading to the releasing of interlayer waters (Colten-Bradley, 1987).

In-situ heat flow measurements in the neighboring Ionian oceanic basin (Della Vedova and Pellis, 1989) and thermal gradient assessed by Mattavelli and Novelli (1990) for oil generation in the southern Sicily foredeep, suggest that the local thermal gradient is about $20 \pm 2{ }^{\circ} \mathrm{C} \mathrm{km}^{-1}$. Based on the geothermometer estimation $\left(T \mathrm{eq}=108 \pm 20^{\circ} \mathrm{C}\right)$, the source of fluids could be located starting at a depth of $3000 \mathrm{~m}$. This depth is compatible both with the total thickness of clay sed-

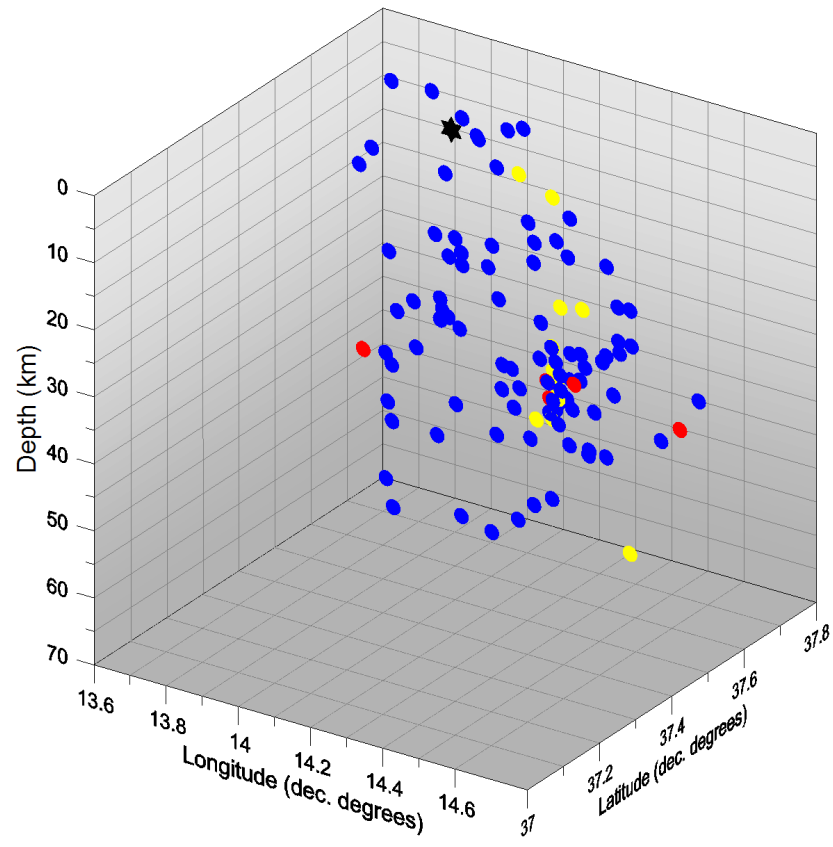

Fig. 12. Hypocentral location of all the seismic events recorded in Central Sicily during the 2002-2009 period. Red circles are the August 2008 events, yellow circles the August 2009 events, blue circles all the others. The black star is the Santa Barbara area.

iments within the Sicilian accrectionary prism $(6000 \mathrm{~m}$, as reported by Monaco and Tortorici, 1996) and the presence of fluids originated from dewatering of sediments trapped in the upper decollements of the prism (Larroque et al., 1996).

\subsection{Relationship with seismic activity}

Central Sicily can be considered an area of low to very low seismic activity, with infrequent and low-intensity seismicity if compared to the eastern sector. Large earthquakes have not been documented for the past centuries in this area (Boschi et al., 1997).

During the observational period (2002-2009), a total of 110 seismic events were recorded; their magnitude mostly ranged between 1 and 2.5, with a highest value outlier of 4.7. An anomaly such as the 4.7 highest value is known as an "outlier". Epicentral distribution of the events is shown in Fig. 11. The 3-D graph of Fig. 12 shows a seismicity generally extended to about $60 \mathrm{~km}$ depth but mainly concentrated from 20 to $40 \mathrm{~km}$; very few events are located in the shallowest region $0-5 \mathrm{~km}$. It can be assumed that the data are generally homogeneously compiled over the whole area and the map is claimed to be representative of the space distribution of activity in the study region.

Under the spatial point of view, a direct relationship between earthquake distribution and MV activity can be excluded, because the hypo- and epicentral locations are 


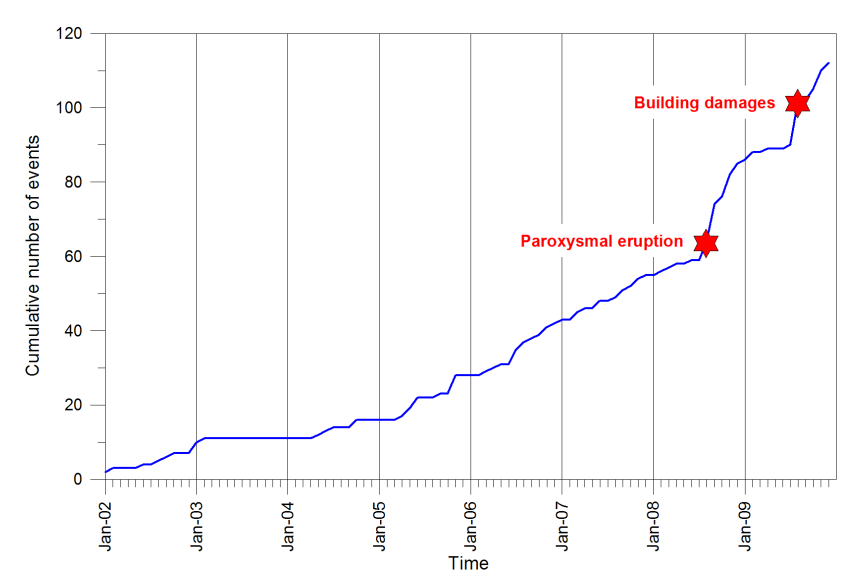

Fig. 13. Cumulative time distribution of the earthquakes recorded in the study area during the observational period; red stars indicate the main paroxysmal events that occurred in 2008 and 2009.

dispersed within a sub-regional seismogenetic volume, with no evidence of tectonic structures passing through or in the vicinity of Santa Barbara area.

Figure 13 shows the cumulative time distribution of the earthquakes recorded during the considered period. As can be seen in the monthly cumulative number of events, the curve exhibits a certain uniformity with constant rate of seismicity with two steps detected in August 2008 and in August 2009. In August 2008, the dataset consisted of recordings of 5 earthquakes with magnitudes ranging from 1.7 to 2.4 in the radius of $10-55 \mathrm{~km}$ from the site. In August 2009, 12 earthquakes with magnitudes ranging from 1.5 to 2.7 in the radius of $20-50 \mathrm{~km}$ from the site were recorded. In both cases, the observed steps are temporally close to the two most significant phenomena occurring in the studied area: the MV paroxysmal eruption in August 2008 and the network of fractures opened in August 2009 at about $250 \mathrm{~m}$ SSE of Vulcanello. More in detail, the August 2008 paroxysm was isochronous with respect to the onset of the anomalous seismic period, whereas the August 2009 event took place after seismicity had already increased. All the seismic events recorded in the two periods were too deep or too far with respect to Santa Barbara MV area for directly relating them to the paroxysm in a time-consistent cause-effect relationship.

The lack of direct spatial relationships and the timing of seismic activity lead to exclude a direct seismically triggered MV paroxysmal activity but, at the same time and as better discussed in the next chapter, the temporal correlation between MV anomalous activity and earthquakes suggests that both phenomena could be parts of a much larger class of crustal unstable processes at work in the area, i.e. "crustal transients" following the definition of Bernard (2001).

\section{Reconstruction of the MV paroxysms phases and consequent landscape evolution}

Based on geochemical data, waters expelled from the Santa Barbara MVs suggest a fluid origin linked to a mixing between a dominant (about 75\%) high-salinity endmember and a low-Cl component. The former is expected to be seawater, initially entrapped in the pores of the sediments and the latter one is consistent with interlayer water of clay minerals which is released during compaction and diagenesis. On the basis of the $\mathrm{Na} / \mathrm{K}$ and $\mathrm{K} / \mathrm{Mg}$ geothemometers, a subsurface temperature around $110^{\circ} \mathrm{C}$ was estimated. Assuming a geothermal gradient of about $20 \pm 2{ }^{\circ} \mathrm{C} \mathrm{km}^{-1}$, a minimum depth of about $3000 \mathrm{~m}$ is inferable for the origin of the fluids or, at least, for their last long-time standing (sufficient to ensure the chemical equilibrium status of the water-rock system) before their emissions on the ground level. According to the classification discussed by Kopf (2002), geochemical and geological data suggest that Santa Barbara MV activity is mainly originated by buoyancy of clay sediments, rich in organic matter, ascending toward the Earth's surface due to a density inversion determined by a considerable amount of seawater trapped in the intergranular spaces at the time of their sedimentation. Moreover, authigenic water derived from early diagenetic dehydration reactions may play an additional role in fluid overpressuring.

As previously discussed, Santa Barbara MVs have been characterized by prolonged periods of mild activity, interrupted by paroxysmal events. This behaviour accounts for a sealed fluid reservoir, progressively overpressured, due to the continuous gas production, since its internal pressure overcomes the lithostatic confining charge. Migration of fluids from the source rock to the near-surface last standing may be favoured by the presence of tectono-stratigraphic discontinuities associated to the regional overthrust limit that separates the Caltanissetta Basin from the northernmost chain (Vallone et al., 2008 and references therein).

Taking into account the very impulsive nature of the 2008 paroxysm, as reported by the eyewitnesses, it was probably due to a strong gas overpressure that generated a gas blast.

The onset a few hours before the paroxysm of a leakage fracture network in the immediate surroundings of the MVs signaled the final step of the pressure overloading, whereas the building damages occurring some kilometers away and all the other fractures that cut the slopes southward from the main emission point were probably due to the ground shaking generated by the near-surface shock wave produced by the gas blast. The absence of any signal of this phenomenon recorded by the regional seismic network is likely due to its very shallow location, within a rock volume made of palaeolandslides poorly coupled with the underlying sediments.

A critical overpressure mainly due to the accumulation of a gaseous phase (methane) is further confirmed by the results of the field surveys. During the first days after the main event 
the emissions were dominated by gaseous phases, whereas mud upwelling resumed its background flow a month after the paroxysm.

MV paroxysms and seismic activity are not in a simple cause-effect relationship.

The direct action of a seismic event as a trigger of the paroxysm can be excluded, because timing and distribution of seismic events are not compatible with the activation of a tectonic discontinuity passing through or in the vicinity of Santa Barbara. On the other hand, taking into account the anomalously high seismic activity recorded both around the 2008 main event and its secondary tail in August 2009, the intensification of a sub-regional stress field responsible for the increase in seismicity, played a seemingly significant role in sparking the impulsive fluid emissions. Moreover, it is noticeable that the maximum number and dimension of emitting vents (September 2008) were reached at the end of the first of the two periods of increased seismic activity, while during the second one (August 2009), the minor paroxysm (fractures and fluid emissions under the edifice 250 SSE from Vulcanello) took place.

Both occurrences support the conviction that a stress field, acting at a spatial scale at least one order of magnitude greater than the study area, could represent the common source for both the seismic and MV activities, even if neither of the two is the cause nor the effect of the other one. As already mentioned, the two phenomena, seismicity and MV activities, are "crustal transients", i.e. instability phenomena characterized by independent source mechanisms, different space and time constrains, and different activation energies needed to generate the impulsive event that will bring the two systems back to a new metastable equilibrium, but with a common trigger: changes in the stress field acting in the rock volume where both phenomena take place. Under this light, the time lags among the MV paroxysms and the earthquakes are only the symptoms that they are moving from different grades of instability, under different change rates of their state, toward different thresholds over which abrupt changes will take place. In other words and following this interpretation, seismic activity and MV paroxysms are both the symptoms of changes in the regional stress field. Their concurrence in the future is likely, if not probable, but their reciprocal timing, i.e. the possibility that MV paroxysms will be the precursors of earthquakes, or vice-versa, is a pseudorandom variable controlled by the extent to which the changing stress field will influence the instability of the two completely separated systems.

\section{Conclusions}

The geomorphological, geochemical, and seismological investigations carried out on the 11 August 2008 paroxysmal event at Santa Barbara MVs, with the associated minor event of August 2009, gave the opportunity to framework the studied phenomena in a wider scale geodynamic context.

In particular, geochemical constrains located the source, or the last standing, of the fluids originating the MV eruptions at about $3 \mathrm{~km}$ depth. Geomorphological surveys allowed us to reconstruct the main steps of the paroxysmal activity, identifying in ground deformations accompanying the last phase of the gas pressure overload and in the consequent shock wave and gas blast, the main causes of all the damages suffered by anthropic structures located in the surroundings of the MV active area. Finally, the close time relationships observed between anomalous increments of seismic activity in the Central Sicily area and the August 2008 and August 2009 events account for a common possible trigger for both the phenomena, even if the very different initial conditions and characteristics of the two processes, i.e. seismogenesis and gas overloading, led to exceeding their critical thresholds at different times. The common trigger can be identified in the evolution of the stress field due to wide-scale geodynamical processes acting in the Central Sicily area.

This interpretation is coherent with the theory of "crustal transients" proposed by Bernard (2001), under whose light most of the crustal phenomena seem to find the way to be correctly understood.

Acknowledgements. We wish to thank L. Brusca, S. Francofonte, and M. Longo (Palermo Branch of the Italian National Institute of Geophysics and Volcanology, INGV) and M. Costa, I. Madonia, and S. Meraviglia (University of Palermo) for their precious help during field surveys and analytical activities. We are also grateful to Lucia Capra (UNAM) and another anonymous reviewer for their suggestions.

Edited by: J. Marti

Reviewed by: L. Capra and another anonymous referee

\section{References}

Abikh, G. V.: New Islands on the Caspian Sea and the Cognition of Mud Volcanoes of the Caspian Region, Mem. Acad. Sci. Peterbourg, Ser. VIII, 6(5), (Translated from the German, Tr. Inst. Geol. Azer., Fil. Akad. Nauk SSSR, 12, 1548 pp., 1939), 1863.

Aliyev, A. A.: Mud volcanism of the South-Caspian oil-gas basin, in South-Caspian Basin: Geology, Geophysics, Oil and Gas Content, 186-212, Nafta, Baku, Azerbaijan, 2004.

Baciu, C. and Etiope, G.: Mud volcanoes and seismicity in Romania, in: Mud Volcanoes, Geodynamics and Seismicity, NATO Sci. Ser. Earth Environ., 51, edited by: Martinelli, G. and Panahi, B., 77-88, Springer, New York, 2005.

Beresnev, I. A. and Johnson, P. A.: Elastic-wave simulation of oil production: A review of methods and results, Geophysics, 59, 1000-1017, 1994.

Bernard, P.: From the search of "precursors" to the research on "crustal transients", Tectonophysics, 338, 225-232, 2001.

Boschi, E., Guidoboni, E., Ferrari, G., Gasperini, P., and Valensise, G.: Catalogo dei forti terremoti in Italia dal 461 a.C. al 1990, ING, Roma, 644 pp., 1997. 
Brown, K. M., Saffer, D. M., and Bekins, B. A.: Smectite diagenesis, pore water freshening and fluid flow at the toe of the Nankai wedge, Earth Planet. Sc. Lett., 194, 97-109, 2001.

Cangemi, M., Di Leonardo, R., Bellanca, A., Cundy, A., Neri, R., and Angelone, M.: Geochemistry and mineralogy of sediments and authigenic carbonates from the Malta Plateau, Strait of Sicily (Central Mediterranean): relationships with mud/fluid release from a mud volcano System, Chem. Geol., 276, 294-308, 2010.

Catalano, S., De Guidi, G., Romagnoli, G., Torrisi, S., Tortorici, G., and Tortorici, L.: The migration of plate boundaries in SE Sicily: Influence on the large-scale kinematic model of the African promontory in southern Italy, Tectonophysics, 449, 4162, 2008.

Chigira, M. and Tanaka, K.: Structural features and the history of mud volcano in southern Hokkaido, northern Japan, J. Geol. Soc. Jpn., 103, 781-793, 1997.

Colten-Bradley, V. A.: Role of pressure in smectite dehydratationeffects on geopressure and smectite/illite transformation, AAPG Bulletin, 71, 1414-1427, 1987.

Dählmann, A. and De Lange, G. J.: Fluid-sediment interactions at eastern Mediterranean mud volcanoes: a stable isotope study from ODP leg 160, Earth Planet. Sc. Lett., 212, 377-391, 2003.

Davies, R., Manga, M., Tingay, M., Lusianga, S., and Swarbrick, R.: Sawolo et al. (2009) the Lusi mud volcano controversy: Was it caused by drilling?, Mar. Petrol. Geol., 27, 1651-1657, 2010.

Delisle, G., von Rad, U., Andruleit, H., von Daniels, C. H., Tabrez, A. R., and Inam, A.: Active mud volcanoes on- and offshore eastern Makran, Pakistan, Int., J. Earth Sci., 91, 93-110, 2002.

Della Vedova, B. and Pellis, G.: New heat flow density measurements in the Ionian Sea, 80 Conv. Naz. GNGTS, CNR, Rome, 1133-1146, 1989.

Dewey, J. F., Helman, M. L., Turco, E., Hutton, D. H. W., and Knott, S. D.: Kinematics of the western Mediterranean, Alpine Tectonics, Geological Society Special Publication, 45, 265-283, 1989.

Dia, A. N., Castrec-Rouelle, M., Boulege, J., and Comeau, P.: Trinidad mud volcanoes where do the expelled fluids come from?, Geochim. Cosmochim. Acta, 63, 1023-1038, 1999.

Dimitrov, L. I.: Mud volcanoes-the most important pathway for degassing deeply buried sediments, Earth-Sci. Rev., 59, 49-76, 2002.

Etiope, G., Caracausi, A., Favara, R., Italiano, F., and Baciu, C.: Methane emission from the mud volcanoes of Sicily (Italy), Geophys. Res. Lett., 29(8), 1215, doi:10.1029/2001GL014340, 2002.

Ferrara, F.: Guida dei viaggiatori agli oggetti più interessanti a vedersi in Sicilia, Palermo, Tip. Abbate, 1836 Monografia - Testo a stampa (IT \ICCU \NAP $\backslash 0159455)$ 6, 1822.

Fitts, T. G. and Brown, K. M.: Stress induced smectite dehydration ramifications for patterns of freshening fluids expulsion in the $\mathrm{N}$. Barbados accretionary wedge, Earth Planet. Sc. Lett., 172, 179197, 1999.

Gat, J. R. and Carmi, H.: Evolution of the isotopic composition of atmospheric waters in the Mediterranean Sea area, J. Geophys. Res., 75, 3039-3040, 1970.

Giggenbach, W. F.: Geothermal solute equilibria. Derivation of NaK-Mg-Ca geoindicators, Geoch. Cosmoch. Acta, 52, 2749-2765, 1988.

Gomberg, J. and Davis, S.: Stress/strain changes and triggered seis- micity at the Geysers, California, J. Geophys. Res., 101, 733749, 1996.

Gomberg, J., Reasenberg, P. A., Bodin, P., and Harris, R. A.: Earthquake triggering by seismic waves following the Landers and Hector Mine earthquakes, Nature, 411, 462-466, 2001.

Graziano, L.: Manifestazioni di vulcanesimo sedimentario nel territorio di Marianopoli (CL). Thesis. Università di Palermo, Italy, 48 pp., 2009.

Gruppo Analisi Dati Sismici: Catalogo dei terremoti della Sicilia Orientale - Calabria Meridionale (1999-2011). INGV, Catania, http://www.ct.ingv.it/ufs/analisti/catalogolist.php, 2011.

Guliyev, I. S. and Feizullayev, A. A.: All About Mud Volcanoes, Inst. of Geol., Azerbaijan Acad. of Sci., Baku, 52 pp., 1995.

Holland, C. W., Etiope, G., Milkov, A. V., Michelozzi, E., and Favali, P.: Mud volcanoes discovered offshore Sicily, Mar. Geol., 199, 1-6, 2003.

Hower, J., Eslinger, E. V., Hower, M. E., and Perry, E. A.: Mechanism of burial metamorphism of argillaceous sediments: 1. Mineralogical and chemical evidence, Geol. Soc. Am. Bull., 87, 725737, 1976.

ICS International Commission on Stratigraphy: International Stratigraphic Chart. Cambridge University Press, 2004.

Kopf, A. J.: Significance of mud volcanism, Rev. Geophys., 40, B1-B49, 2002.

Lahr, J. C.: HYPOELLIPSE: A computer program for determining local earthquake hypocentral parameters, magnitude, and first motion pattern, (Y2K compliant version) U.S. Geological Survey Open-File Report 99-23, 112 pp., 1999.

Larroque, C., Guilhaumou, N., Stephan, J. F., and Roure, F.: Advection of fluids at the front of the Sicilian Neogene subduction complex, Tectonophysics, 254, 41-55, 1996.

Li Volsi, S.: Memoria sul vulcano aereo (ossia gasoso) (I) di Terrapilata in Caltanissetta dell'abate Salvatore Li Volsi, dedicata a S. E. sig. March. Delle Favare Ministro Segretario di Stato, Luogotenente Generale in Sicilia. Giornale di Scienze, Lettere ed Arti per la Sicilia, Tomo XIII, Anno IV, Gennajo, Febbrajo e Marzo, Palermo Presso Lorenzo Dato, 1826.

Lickorish, W. H., Grasso, M., Butler, R. W. H., Argnani, A., and Maniscalco, R.: Structural styles and regional tectonic setting of the "Gela Nappe" and frontal part of the Maghrebian thrust belt in Sicily, Tectonics, 18, 655-668, 1999.

Linde, A. T. and Sacks, I. S.: Triggering of volcanic eruptions, Nature, 395, 888-890, 1998.

Magaritz, M. and Gat, J. R.: Review of the natural abundance of hydrogen and oxygen isotopes, in: Stable Isotopes Hydrology Deuterium and Oxygen-18 in the water cycle, edited by: Gat, J. R. and Gonfiantini, R., Technical reports series 210, International Atomic energy Agency, Vienna, 85-102, 1981.

Martin, J. B., Kastner, M., Henry, P., Le Pichon, X., and Lallemant, S.: Chemical and isotopic evidence for sources of fluids in a mud volcano field seaward of the Barbados accretionary wedge, J. Geophys. Res., 101, 20325-20345, 1996.

Martinelli, G. and Dadomo, A.: Volcano monitoring and seismic events, in Mud Volcanoes, Geodynamics and Seismicity, NATO Sci. Ser. Earth Environ., 51, edited by: Martinelli, G. and Panahi, B., Springer, New York, 211-220, 2005.

Mattavelli, L. and Novelli, L.: Geochemistry and habitat of the oils in Italy, Am. Assoc. Pet. Geol. Bull. 74, 1623-1639, 1990. 
Mazurenko, L. L., Soloviev, V. A., Gardner, J. M., and Ivanov, M. K.: Gas hydrates in the Ginsburg and Yuma mud volcano sediments (Moroccan Margin): results of chemical and isotopic studies of pore water, Mar. Geol., 195, 201-210, 2003.

Mazzini, A., Nermoen, A., Krotkiewski, M., Podladchikov, Y., Planke, S., and Svensen, H.: Strike-slip faulting as a trigger mechanism for overpressure release trough piercement structures. Implications for the Lusi mud volcano, Indonesia, Mar. Petrol. Geol, 26, 1751-1765, 2009.

Mellors, L., Kilb, D., Aliyev, A., Gasanov, A., and Yetirmishli, G.: Correlations between earthquakes and large mud volcano eruptions, J. Geophys. Res., 112, B04304, doi:10.1029/2006JB004489, 2007.

Monaco, C. and Tortorici, L.: Clay diapirs in Neogene-Quaternary sediments of central Sicily: evidence for accretionary processes, J. Struct. Geol., 18, 1265-1269, 1996.

Murray, J. W., Grundmanis, V., and Smethie, W. M. Jr.: Interstitial water chemistry in the sediments of Saanich inlet, Geochim. Cosmochim. Acta, 42, 1011-1026, 1978.

Ogniben, L.: Le argille brecciate Siciliane, Mem. Ist. Geol. Mineral. Univ. Padova, 18, 1-92, 1954.

Parkhurst, D. L. and Appelo, C. A. J.: User's guide to PHREEQC A computer program for speciation, batch-reaction, one-dimensional transport, and inverse geochemical calculations: U.S. Geological Survey Water-Resources Investigations Report 99-4259, 312 pp., 1999.
Roeloffs, E., Sneed, M., Galloway, D. L., Sorey, M. L., Farrar, C. D., Howle, J.-F., and Hughes, J.: Water-level changes induced by local and distant earthquakes at Long Valley caldera, California, J. Volcanol. Geotherm. Res., 127, 269-303, 2003.

Savini, A., Malinverno, E., Etiope, G., Tessarolo, C., and Corselli, C: Shallow seep-related seafloor features along the Malta plateau (Sicily channel-Mediterranean Sea): Morphologies and geoenvironmental control of their distribution, Mar. Petrol. Geol., 26, 1831-1848, 2009.

Sawolo, N., Sutriono, E., Istadi, B., and Darmoyo, A. B.: The LUSI mud volcano controversy: was it caused by drilling?, Mar. Petrol. Geol., 26, 1766-1784, 2009.

Serpelloni, E., Vannucci, G., Pondrelli, S., Argnani, A., Casula, G., Anzidei, M., Baldi, P., and Gasperini, I.: Kinematics of the Western Africa-Eurasia plate boundary from focal mechanisms and GPS data, Geophys. J. Int., 169, 1180-1200, 2007.

Vallone, P., Giammarinaro, M. S., Crosetto, M., Agudo, M., and Biescas, E.: Ground motion phenomena in Caltanissetta (Italy) investigated by InSAR and geological data integration, Eng. Geol., 98, 144-155, 2008.

You, C. F., Gieskes, J. M., Lee, T., Yui, T. F., and Chen, H. W.: Geochemistry of mud volcano fluids in the Taiwan accretionary prism, Appl. Geochem., 19, 695-707, 2004.

Zuber, A. and Chowaniec, J.: Diagenetic and other highly mineralized waters in the Polish Carpathians, Appl. Geochem., 24, 1889-1900, 2009. 